himself conspicuous by habits of absurd braggadocio, which led those with whom he associated to regard him as insane, and as subject to delusions of grandeur. The offence was committed with scarcely any precautions in the way of concealment, and was of a nature that, considering the position and the age of the prisoner, of itself suggested insanity. On the other hand, it was proved that even up to the time of the offence the prisoner was capable of transacting difficult business in a thoroughly efficient manner.-Guilty, but insane.-Carlisle Assizes, November 4th (Mr. Justice Phillimore).-East Cumberland News, November 5th.

Reg. v. Yeo.

Henry Yeo was indicted for publishing libels concerning Dr. Bevan Lewis, Superintendent of the West Riding Asylum. The prisoner was the editor of a weekly paper called the $S p y$, published at Manchester, and in 1896 , while undergoing a sentence of twelve months' imprisonment for libel, he was transferred from prison to the West Riding Asylum as a criminal lunatic. He appears to have been released at the expiration of his sentence, and subsequently published in his paper a series of articles containing gross libels upon Dr. Bevan Lewis. The prisoner defended himself, and in his address to the jury he alleged that Dr. Lewis, by means of some electrical apparatus or patent process, could tell what he was doing wherever he was. He appealed to the judge to inquire into his persecution and to order an expert to examine the asylum and discover the apparatus by which the persecution had been effected. The jury found the prisoner guilty, and he was sentenced to twelve months' imprisonment. The prisoner's wife, who had assisted in publishing the libels, pleaded guilty to this offence, and in sentencing her the judge said that as her husband was subject to delusions, and could scarcely be held responsible for what he did, she had done very wrong to assist him.-Yorkshire Assizes, August ist (Mr. Justice Grantham).-Times, August 2nd.

Reg. v. Anderson.

James Anderson, 45, ship carpenter, was indicted for the murder of his wife. Prisoner was of intemperate habits, and often quarrelled with his wife. The evening of the murder the two appeared to be on exceptionally amicable terms, but at about 8 p.m. the neighbours heard a disturbance, and it was found that the prisoner had killed his wife by cutting her throat, and had then inflicted a severe wound upon his own. It appears that he believed that his wife exerted a "spell power" over him, and could make him, even when he was away from her, do deeds that he would have shrunk from; that she tried to poison him with beetroot and onions; that others besides his wife were his enemies, and were trying to thwart him in every way, and were conspiring against him; and that for the last twenty years his relatives have regarded him as insane. He was found unfit to plead, and ordered to be detained during her Majesty's pleasure.-(Lord Trayner).-Scotsman, September 17th.

\title{
AFTER-CARE ASSOCIATION.
}

The annual meeting will be held on Monday, February 6th, 1899, at 72, Grosvenor Street, W., the residence of Sir Samuel Wilks, President of the Royal College of Physicians, who will preside. The past year has been, we are informed, by far the most successful one in the annals of the Association, both in the number of cases assisted and in the amount of the subscriptions. Unfortunately the subscription of 650 , promised by Mr. Mocatta if 61000 were raised during the year, cannot be claimed.

The active assistance of the Medical Superintendents of Asylums is earnestly sought: many have long given it the most energetic support, but it is hoped that the increased means and experience of the Association will enable it to deal even more satisfactorily with the cases in future entrusted to it than it has done in the past. 